Zeszyty Naukowe Szkoły Głównej Gospodarstwa Wiejskiego

Ekonomika i Organizacja Gospodarki Żywnościowej nr 113, 2016: 17-32

Piotr Kułyk, Mariola Michałowska

Katedra Ekonomii Międzynarodowej, Wydział Ekonomii i Zarządzania

Uniwersytet Zielonogórski

\title{
Stan rozwoju rolnictwa ekologicznego w Polsce w latach 2004-2014
}

\section{Wstęp}

W XXI wieku wobec niekorzystnych następstw społecznych i środowiskowych spowodowanych intensywnym rozwojem gospodarczym szczególnego znaczenia nabiera problem zrównoważonej produkcji i konsumpcji. $Z$ jednej strony sektor rolny jest kluczowym elementem koncepcji zrównoważonego rozwoju, gdyż jego funkcjonowanie i rozwój opiera się na wykorzystaniu zasobów naturalnych, z drugiej zaś istotną rolę odgrywa zrównoważona konsumpcja, przez którą rozumie się kwestie związane $\mathrm{z}$ prawidłowym funkcjonowaniem świata, współdziałaniem jego elementów, takich jak: ekologią, zdrowiem, lokalnością, poszanowaniem praw człowieka przy procesie produkcji [Dąbrowska, Bylok, Janoś-Kresło, Kiełczewski i Ozimek 2015, s. 103]. Niekorzystne efekty, jakie ujawniły się w wyniku dominacji rolnictwa industrialnego, ujawniły konieczność zmiany dotychczasowego podejścia w rozwoju rolnictwa, zwłaszcza w krajach, gdzie uzyskano znaczne nadwyżki w produkcji rolnej. Jednym z możliwych kierunków przemian w tym zakresie jest rozwój rolnictwa ekologicznego. Głównym celem opracowania jest przedstawienie stanu i przewidywanych tendencji rozwoju rolnictwa ekologicznego w Polsce, a także wskazanie na istotną rolę konsumentów w procesie jego rozwoju. Dlatego też ukazano strukturę wydatków w polskich gospodarstwach domowych, w tym poziom wydatków przeznaczonych na żywność ekologiczną na tle krajów o największych wydatkach na żywność ekologiczną na jednego mieszkańca. W opracowaniu przyjęto tezę, że rozwojowi rynku żywności sprzyja nie tylko rosnąca zamożność społeczeństwa, ale także coraz większa świadomość ekologiczna. Dostrzeżenie zależności między żywnością, którą codziennie spożywamy a poziomem samopoczucia

\footnotetext{
${ }^{1}$ Zrealizowano przy pomocy finansowej Miasta Zielona Góra.
} 
i stanem zdrowia staje się kluczowe w rosnącym popycie na te produkty. W przeprowadzonych analizach wykorzystano wtórne źródła informacji pochodzące z baz danych Eurostatu, GUS, raportów dotyczących rolnictwa, a także dostępnych wyników badań odnoszących się do podejmowanej problematyki.

\section{Koncepcja rolnictwa ekologicznego w świetle zrównoważonego modelu rolnictwa}

Rolnictwo ekologiczne, jak podaje Nowa encyklopedia powszechna PWN, to „system gospodarowania zrównoważonego ekologicznie, który ogranicza ingerencję człowieka w ekosystem, jest w dużym stopniu niezależny od nakładów zewnętrznych, a także umożliwia zachowanie i rozwój wsi oraz rolnictwa jako kategorii społecznych i kulturowych; celem rolnictwa ekologicznego jest ochrona gleby, wody i krajobrazu, zapewnienie biologicznych samoregulacji w obrębie gospodarstwa oraz utrzymanie wysokiej jakości biologicznych produktów rolnych" [Baturo i in. 2004, s. 667-668]. Jest to zatem system zrównoważony pod względem środowiskowym, ekonomicznym i społecznym. Rolnictwo ekologiczne określane jest jako rolnictwo naturalne, organiczne, biologiczne ${ }^{2}$. Termin „rolnictwo ekologiczne” upowszechnił się dopiero w 1989 roku, gdyż wówczas 1 września zarejestrowano Stowarzyszenie Producentów Żywności Metodami Ekologicznymi „EKOLAND”.

Rolnictwo ekologiczne wpisując się w koncepcję rozwoju zrównoważonego, prowadzi do wielu zróżnicowanych korzyści:

- ekonomiczno-społecznych, gdyż zapobiega nadmiernemu odpływowi ludności wiejskiej, pozwala utrzymać miejsca pracy na wsi, jest energooszczędne;

- środowiskowych, przyczyniając się do zwiększenia żyzności gleby, zachowuje różnorodność biologiczną w minimalnym stopniu obciąża środowisko;

- zdrowotnych, gdyż zapewnia wysoką wartość odżywczą produktów, dostarcza produkty o wysokiej wartości zdrowotnej;

- etyczno-estetycznych, wśród których można wyróżnić m.in.: zachowanie zróżnicowanego krajobrazu rolniczego, kierowanie się zasadami etyki środowiskowej [Łuczka-Bakuła 2007, s. 42].

Warto również zauważyć, że obok korzyści, jakie przynosi rolnictwo ekologiczne, jego słabymi stronami są m.in.: mniejsze plony niż uzyskane na plantacjach konwencjonalnych - średnio o $20 \%$, dotyczy to również produkcji zwierzęcej, mleka i mięsa, większa pracochłonność produkcji ekologicznej, jak również wyższe ceny produktów ekologicznych [Żelezik 2009, s. 164].

\footnotetext{
${ }^{2}$ Terminy te zostały na mocy rozporządzenia EWG nr 2092/91 uznane za synonimy.
} 
Koncepcja zrównoważonego rozwoju oznacza konieczność zapewnienia sprawiedliwości zarówno międzypokoleniowej na osi czasu, jak i wewnątrzpokoleniowej. Pierwsza odnosi się do zachowania ekosystemów i dóbr społecznych dla przyszłych pokoleń. Rozwój rolnictwa ekologicznego spełnia ten warunek w tym zakresie, iż ogranicza niekorzystne oddziaływanie produkcji rolnej na kapitał naturalny. Pozwala przestrzegać granic biologicznych i zasobów naturalnych, a także zachować zasoby na potrzeby produkcji w przyszłości [Zegar 2012, s. 21-22]. Odnośnie roli rolnictwa ekologicznego powstaje ważny dylemat, czy zmniejszenie efektywności technologicznej na skutek ograniczenia chemizacji oraz częściowo mechanizacji nie ograniczy dostępności żywności zwłaszcza w ujęciu globalnym. Podważałoby to możliwość zachowania równowagi wewnątrzpokoleniowej. Jednak uwzględniając trwałą degradację zasobów, jaka może wystapić w warunkach nadmiernej intensywności produkcji rolnej, w tym zwłaszcza chemizacji [Clay 2013, s. 133], można przyjąć, iż nie jest to do końca prawdziwe. Następuje równocześnie zwiększenie wielu dodatkowych korzyści, które w warunkach rolnictwa industrialnego nie są przez system rynkowy wartościowane (np. liczne dobra publiczne). Otwarte pozostaje natomiast pytanie, jaką rolę odegra rolnictwo ekologiczne w globalnym systemie produkcji rolnej w przyszłości.

\section{Rozwój rolnictwa ekologicznego w Polsce}

W Polsce rolnictwo ekologiczne dynamicznie się rozwija, jednak wciąż jego znaczenie nie jest wielkie w łącznej produkcji rolnej. W 2013 roku powierzchnia użytków rolnych, na których prowadzona była produkcja ekologiczna, stanowiła 4,6\% wszystkich użytków rolnych w Polsce, a w 2014 roku udział ten wyniósł 4,5\% [Dane GUS, Rolnictwo w 2014 ...2015, s. 21]. Na tle innych państw UE jest to wynik przeciętny. Wśród krajów UE o największym udziale powierzchni przeznaczonej dla produkcji ekologicznej znajdują się m.in.: Austria, Szwecja, Estonia, Czechy (tabela 1). Rolnictwo ekologiczne wykazuje równocześnie znaczne zróżnicowanie pomiędzy poszczególnymi krajami zarówno w zakresie udziału w powierzchni, jak i jej dynamiki na przestrzeni lat 2005-2012. Wysoki przyrost występował zwłaszcza wśród części państw, które przystąpiły do UE po 2003 roku i zostały objęte wspólną polityką rolną. Stwierdzone zjawisko ma zatem charakter kontekstowy, uzależnione jest od warunków lokalnych czy szerzej regionalnych oraz stymulacji za pomocą systemu instytucjonalnego. Zwiększa możliwości konkurowania określonych obszarów rolnych poprzez większe zaakcentowanie cech jakościowych jako przeciwwagi do konkurencyjności kosztowej opartej na efektywności technologicznej. 
Tabela 1

Udział powierzchni przeznaczonej na produkcję ekologiczną w UE w latach 2003-2012 [w \% użytków rolnych ogółem]

\begin{tabular}{|c|c|c|c|c|c|c|c|c|c|c|c|}
\hline \multirow{2}{*}{$\begin{array}{l}\text { Wyszcze- } \\
\text { gólnienie }\end{array}$} & \multicolumn{10}{|c|}{ Rok } & \multirow{2}{*}{$\begin{array}{c}\begin{array}{c}\text { Dyna- } \\
\text { mika* }\end{array} \\
2012 / \\
\text { /2005 } \\
\end{array}$} \\
\hline & 2003 & 2004 & 2005 & 2006 & 2007 & 2008 & 2009 & 2010 & 2011 & 2012 & \\
\hline EU-27 & - & - & $3,6(e)$ & $3,7(e)$ & $4(e)$ & $4,4(e)$ & $4,7(e)$ & $5,2(e)$ & $5,5(e)$ & $5,7(e)$ & 158,33 \\
\hline Austria & 15,4 & 16,0 & 16,7 & 16,7 & 17,0 & 17,4 & 18,5 & 19,5 & 19,6 & 18,6 & 111,38 \\
\hline Belgia & 1,7 & 1,7 & 1,7 & 2,1 & 2,4 & 2,6 & 3,0 & 3,6 & 4,1 & $4,4(e)$ & 258,82 \\
\hline Bułgaria & - & - & $0,2(e)$ & 0,1 & 0,3 & 0,3 & 0,2 & 0,5 & 0,5 & 0,8 & 400,00 \\
\hline Cypr & - & 0,6 & 1,0 & 1,2 & 1,5 & $1,6(e)$ & 2,6 & $2,8(e)$ & $2,9(e)$ & 3,4 & 340,00 \\
\hline Czechy & 7,0 & 7,2 & 7,1 & 7,2 & 8,2 & 9,0 & 10,6 & 12,4 & 13,1 & $13,1(e)$ & 184,51 \\
\hline Dania & 6,3 & 5,8 & 4,9 & 5,1 & $5(e)$ & 5,6 & 5,9 & 6,1 & 6,1 & 7,3 & 148,98 \\
\hline Estonia & - & $7,2(e)$ & 7,2 & 9,6 & 8,7 & 9,6 & 11 & 12,8 & 14,1 & 14,9 & 206,94 \\
\hline Finlandia & 7,1 & 7,2 & 6,5 & 6,3 & 6,6 & 6,5 & 7,2 & 7,4 & 8,2 & 8,7 & 133,85 \\
\hline Francja & 1,9 & 1,8 & 1,9 & 1,7 & 1,9 & 2,0 & 1,9 & 2,9 & 3,4 & 3,6 & 189,47 \\
\hline Grecja & 6,4 & 6,5 & 7,6 & 7,6 & 7,0 & 7,8 & 8,5 & 8,4 & 5,2 & 11,1 & 146,05 \\
\hline Hiszpania & 2,9 & $2,9(e)$ & 3,1 & 3,7 & 4,0 & 5,3 & 6,6 & $6,7(e)$ & 7,5 & 7,5 & 241,94 \\
\hline Holandia & 2,2 & & 2,5 & 2,5 & 2,5 & 2,6 & 2,6 & 2,5 & 2,5 & & 104,00 \\
\hline Irlandia & 0,7 & & 0,8 & 0,9 & 1,0 & & 1,1 & $1,1(e)$ & $1,1(e)$ & $1,1(e)$ & 137,50 \\
\hline Litwa & - & 1,4 & 2,3 & 3,5 & 4,5 & 4,6 & 4,8 & 5,2 & 5,4 & 55 & 239,13 \\
\hline $\begin{array}{l}\text { Luksem- } \\
\text { burg }\end{array}$ & 2,3 & 2,5 & $2,4(e)$ & $2,4(e)$ & 2,6 & 2,7 & $2,7(e)$ & $2,8(e)$ & $2,8(e)$ & $2,7(e)$ & 112,50 \\
\hline Łotwa & - & 1,6 & 6,8 & 9,4 & 8,1 & 8,9 & 8,7 & 9,2 & 10,1 & 10,6 & 155,88 \\
\hline Malta & - & 0 & 0,1 & 0,2 & $0,3(e)$ & $0,4(e)$ & $0,5(e)$ & 0,2 & $0,2(e)$ & 0,3 & 300,00 \\
\hline Niemcy & 4,3 & 4,5 & 4,7 & 4,9 & 5,1 & 5,4 & 5,6 & 5,9 & 6,1 & $5,8(b)$ & 123,40 \\
\hline Polska & 0,2 & 0,5 & 1,0 & 1,0 & 1,8 & 2,0 & 2,3 & 3,3 & 4,1 & 4,6 & 460,00 \\
\hline Portugalia & 3,2 & 5,6 & 6,2 & 7,2 & 6,3 & 5,7 & 4,3 & 5,8 & 6,1 & $6,1(e)$ & 98,39 \\
\hline Rumunia & - & - & $0,7(e)$ & 0,8 & 1,0 & 1,0 & 1,2 & 1,3 & 1,6 & 2,1 & 300,00 \\
\hline Słowacja & 2,2 & 2,6 & 4,6 & 6,2 & 6,1 & 7,3 & 7,5 & 9,1 & 8,6 & $8,6(e)$ & 186,96 \\
\hline Słowenia & & 4,6 & 4,6 & 5,5 & 5,9 & 6,1 & 6,3 & 6,4 & 7,0 & 7,3 & 158,70 \\
\hline Szwecja & 7,2 & 7,0 & 7,0 & 7,2 & 9,9 & 10,9 & 12,8 & 14,3 & 15,7 & 15,8 & 225,71 \\
\hline Węgry & 2,0 & 2,3 & 2,2 & 2,1 & 1,8 & 2,1 & 2,4 & 2,4 & 2,3 & 2,4 & 109,09 \\
\hline $\begin{array}{l}\text { Wielka } \\
\text { Brytania }\end{array}$ & 3,9 & 3,9 & 3,5 & 3,4 & 3,7 & 4,1 & 4,2 & 4,1 & 3,7 & $3,4(e)$ & 97,14 \\
\hline Włochy & 7,0 & 6,4 & 7,3 & $7,9(e)$ & 7,9 & 7,5 & $8,1(e)$ & 8,6 & 8,4 & $8,9(e)$ & 121,92 \\
\hline
\end{tabular}

b - break in time series, czyli przerwa w szeregu czasowym, e-estimated, czyli wartość szacunkowa, "przeliczona jako wartość z 2012 roku przez wartość z 2005 roku (z uwagi na dostępność danych).

Źródło: Eursostat, http://appsso.eurostat.ec.europa.eu/nui/submitViewTableAction.do, [dostęp: 15.09.2015]. 
W latach 2004-2014 liczba ekologicznych producentów ${ }^{3}$ rolnych w Polsce wzrosła ponad 6-krotnie z 3705 w 2004 roku do 24829 w 2014 roku. Warto zauważyć, że w latach 2004-2013 odnotowywano wzrost liczby ekologicznych producentów rolnych, a w 2014 roku ich liczba zmniejszyła się o 1769 w porównaniu z 2013 rokiem ${ }^{4}$, co oznacza spadek w stosunku do poprzedniego roku średnio o 7\% (rysunek 1). W 2014 roku nastapił natomiast wzrost liczby przetwórni ekologicznych ${ }^{5}$ (rysunek 2). Jak wynika z danych zamieszczonych na rysunku 1, w latach 2004-2005 nastapił dynamiczny wzrost liczby ekologicznych producentów rolnych. W 2005 roku w porównaniu do 2004 roku liczba producentów wzrosła średnio o 94\%, czyli nastapił prawie dwukrotny wzrost liczby ekologicznych producentów rolnych. Niewątpliwie jedną z głównych przyczyn zwiększenia się ich liczby było wprowadzenie dopłat do ekologicznej produkcji rolnej dla gospodarstw posiadających certyfikat produkcji ekologicznej, a także

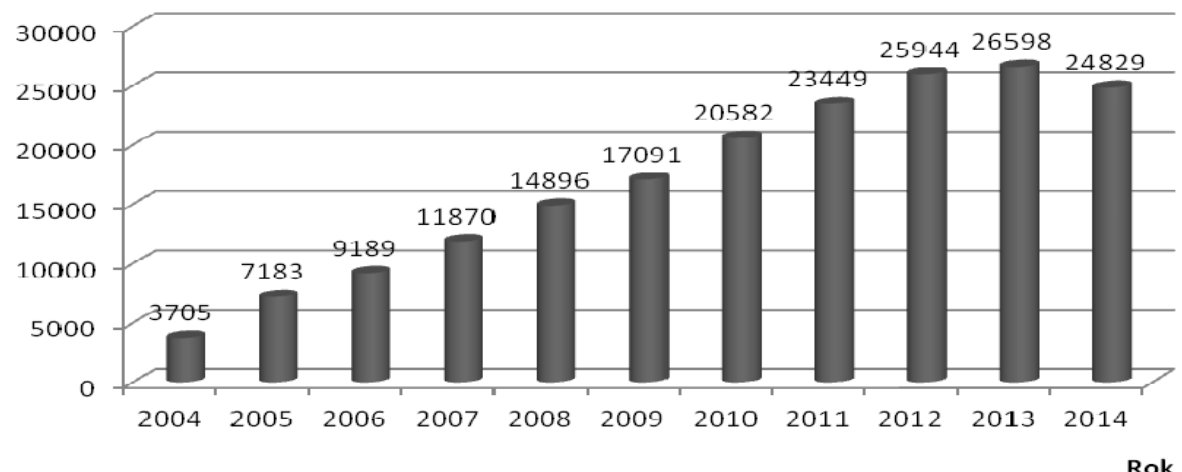

\section{Rysunek 1}

Liczba ekologicznych producentów rolnych w Polsce w latach 2004-2014

Źródło: Raport o stanie rolnictwa ekologicznego w Polsce w latach 2013 i 2014, Inspekcja Jakości Handlowej Artykułów Rolno-Spożywczych, Warszawa 2015, s. 19, http://www.ijhars.gov.pl/pliki/A-pliki-z-glownego-katalogu/ethernet/2015/wrzesien/Raport\%200\%20stanie\%2 Orolnictwa\%20ekologicznego\%20w\%20Polsce\%20w\%20latach\%202013-2014.pdf [dostęp: 15.09.2015].

\footnotetext{
${ }^{3}$ Producenci ekologiczni w rozumieniu art. 2 pkt 2 ustawy z dnia 25 czerwca 2009 roku o rolnictwie ekologicznym (Dz.U. nr 116, poz. 975, z późn. zm.) to wszystkie podmioty, które podjęy działalność w zakresie rolnictwa ekologicznego i są pod kontrolą jednostki certyfikującej.

${ }^{4}$ Spadek ten można wiązać m.in. ze zmianami w systemie wsparcia związanymi ze wzrostem wymogów stawianych producentom ekologicznym.

${ }^{5}$ Rozporządzenie Rady (WE) nr 834/2007 z dnia 28 czerwca 2007 r. w sprawie produkcji ekologicznej i znakowania produktów ekologicznych (Dz.Urz. L 189/1 z 20.07.2007 r.) określa zasady przetwarzania surowców $\mathrm{z}$ rolnictwa ekologicznego $\mathrm{w}$ produkty handlowe oraz zasady ich znakowania, z odniesieniem do rolnictwa ekologicznego. Zgodnie z rozporządzeniem za przetworzony produkt ekologiczny, uznaje się taki, który podlegał ekologicznemu przetwórstwu przy użyciu takich metod przetwarzania, które gwarantują przestrzeganie zasad produkcji ekologicznej i utrzymanie zasadniczych cech produktu na wszystkich etapach produkcji.
} 


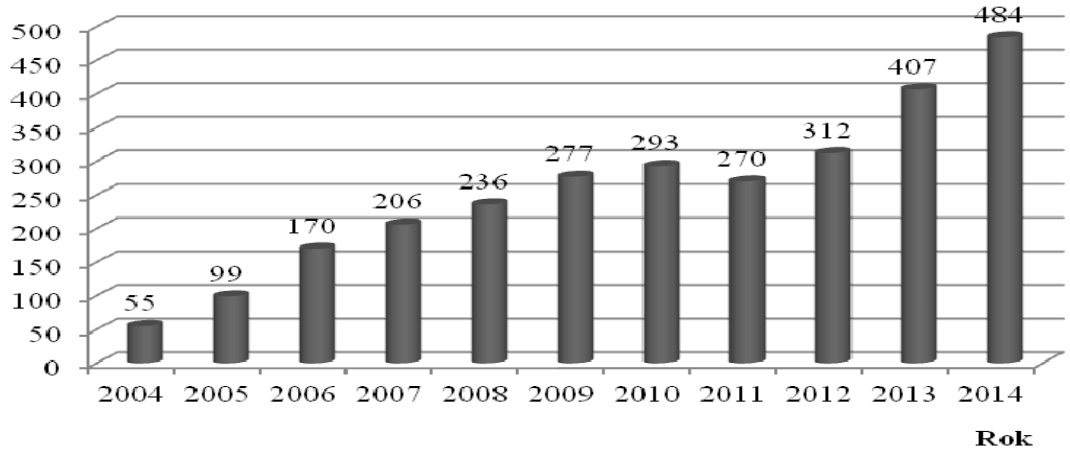

\section{Rysunek 2}

Liczba przetwórni ekologicznych w Polsce w latach 2004-2014

Źródło: Raport o stanie rolnictwa ekologicznego w Polsce w latach 2013 i 2014, Inspekcja Jakości Handlowej Artykułów Rolno-Spożywczych, Warszawa 2015, s. 19, http://www.ijhars.gov.pl/pliki/A-pliki-z-glownego-katalogu/ethernet/2015/wrzesien/Raport\%20o\%20stanie\%2 Orolnictwa\%20ekologicznego\%20w\%20Polsce\%20w\%20latach\%202013-2014.pdf [dostęp: 15.09.2015].

będących w trakcie przestawiania gospodarstwa na produkcję metodami ekologicznymi. Stąd też można przypuszczać, że wzrost ich wynikał z faktu, że wielu producentów ubiegało się o certyfikat ze względu na wcześniej wspominane dopłaty. Kolejne zmiany we wspólnej polityce rolnej coraz bardziej wspieraja model rolnictwa społecznie zrównoważonego, w tym także rolnictwa ekologicznego. Jest to silny impuls dla wzrostu znaczenia tego segmentu, zawłaszcza iż o możliwościach rozwoju tego rolnictwa w stosunku do rolnictwa konwencjonalnego przesądza poziom generowanych dochodów [Runowski 2009, s. 192], ten natomiast jest $\mathrm{w}$ dużym stopniu $\mathrm{w}$ krajach UE kształtowany przez system różnych dopłat w ramach wspólnej polityki rolnej [Kułyk 2013, s. 169-170].

W kolejnych latach można zaobserwować niższą dynamikę wzrostu ekologicznych gospodarstw rolnych. Jak już wspomniano, w 2014 roku liczba producentów zmniejszyła się w stosunku do 2013 roku średnio o $7 \%{ }^{6}$, wzrosła zaś liczba przetwórni ekologicznych. Trzeba jednak zauważyć, iż dynamiczny wzrost liczby gospodarstw i powierzchni użytków rolnych do 2013 roku nie prowadził do równie szybkiego zwiększenia ekologicznej produkcji rolnej. Znaczna czesść tych obszarów tylko pośrednio wiązała się z produkcją ekologiczną (np. duży udział powierzchni trawiastych) [Szanse i zagrożenia polskiego 2013, s. 6]. Strukturę ekologicznych użytków rolnych w Polsce w latach 2013 i 2014 ukazano w tabeli 2.

\footnotetext{
${ }^{6}$ Spadek ten można wiązać m.in. ze zwiększeniem restrykcyjności w zakresie wsparcia w ramach PROW - Rolnictwo ekologiczne, co w konsekwencji zmniejszyło dostępność tych środków dla rozważanej grupy gospodarstw rolnych.
} 
Tabela 2

Struktura ekologicznych użytków rolnych w Polsce w latach 2013 i 2014

\begin{tabular}{|l|c|c|}
\hline \multirow{2}{*}{ Kategoria uprawy } & \multicolumn{2}{|c|}{$\begin{array}{c}\text { Udział powierzchni użytków rolnych dla danej kategorii } \\
\text { uprawy [\% }\end{array}$} \\
\cline { 2 - 3 } & 2013 roku & 2014 roku \\
\hline Rośliny na pasze & 35,8 & 35,8 \\
\hline Łaki i pastwiska & 30,2 & 31,5 \\
\hline Zboża & 18,4 & 16,9 \\
\hline $\begin{array}{l}\text { Uprawy sadownicze } \\
\text { i jagodowe }\end{array}$ & 9,5 & 8,9 \\
\hline Warzywa & 3,7 & 4,1 \\
\hline $\begin{array}{l}\text { Rośliny strączkowe na suche } \\
\text { nasiona }\end{array}$ & 0,9 & 1,1 \\
\hline Rośliny przemysłowe & 0,7 & 0,7 \\
\hline Ziemniaki & 0,4 & 0,4 \\
\hline Pozostałe uprawy & 0,4 & 0,6 \\
\hline
\end{tabular}

Źródło: Raport o stanie rolnictwa ekologicznego w Polsce w latach 2013 i 2014, Inspekcja Jakości Handlowej Artykułów Rolno-Spożywczych, Warszawa 2015, s. 21-22, http:// www.ijhar-s.gov.pl/pliki/A-pliki-z-glownego-katalogu/ethernet/2015/wrzesien/Raport\%20 0\%20stanie\%20rolnictwa\%20 kologicznego $\% 20$ w $\% 20$ Polsce $\% 20$ w $\% 20$ latach $\% 20201$ 3-2014.pdf [dostęp: 15.09.2015].

Jak wynika z danych zamieszczonych na rysunku 2, liczba przetwórni wykazuje tendencję wzrostową, z wyłączeniem 2011 roku. Wówczas odnotowano spadek liczby przetwórni w porównaniu do poprzedniego roku o 23 podmioty. W $2014 \mathrm{r}$. w Polsce było 484 przetwórni. Wzrost przetwórni w latach 2004-2014 był o 210 pkt proc. szybszy od zwiększenia liczby ekologicznych gospodarstw rolnych. Tworzyło to korzystną przestrzeń dla zagospodarowania ekologicznych produktów rolnictwa. W konsekwencji liczba ekologicznych gospodarstw przypadająca na jedną przetwórnię ekologiczną zmniejszyła się z 67 w 2004 roku do 51 w 2014.

W 2014 roku największy udział w powierzchni użytków rolnych miały rośliny na paszę $(35,8 \%)$. Na drugim miejscu znajdowały się łąki i pastwiska $(31,5 \%)$, na trzecim zboża, które zajmowały $16,9 \%$ użytków rolnych. Uprawy sadownicze i jagodowe stanowiły $8,9 \%$, warzywa zaś $4,1 \%$. Rośliny strączkowe na suche nasiona zajmowały $1,1 \%$ powierzchni użytków rolnych. Rośliny przemysłowe stanowiły $0,7 \%$, a ziemniaki $0,4 \%$. Pozostałe grupy upraw zajmowały łącznie $0,6 \%$ użytków rolnych. Jak wynika z danych, w Polsce ponad $67 \%$ użytków rolnych stanowią rośliny na paszę oraz łąki i pastwiska. 


\section{Polski konsument wobec rynku żywności ekologicznej}

Poziom przeciętnych miesięcznych nominalnych dochodów rozporządzalnych na osobę w gospodarstwie domowym w 2014 roku w Polsce wyniósł 1340 zł, wydatki nominalne zaś kształtowały się na poziomie 1079 zł. W 2014 roku sytuacja materialna gospodarstw domowych poprawiła się, gdyż wzrosła nadwyżka dochodów nad wydatkami w porównaniu do 2013 roku, pomimo większych wydatków (rysunek 3). Wzrost dochodów rozporządzalnych na przestrzeni lat 2000-2014 (rysunek 3) kształtował korzystne warunki dla wzrostu konsumpcji ekologicznej (popytu konsumpcyjnego), a w konsekwencji wzrostu ekologicznej produkcji rolnej (podaży).

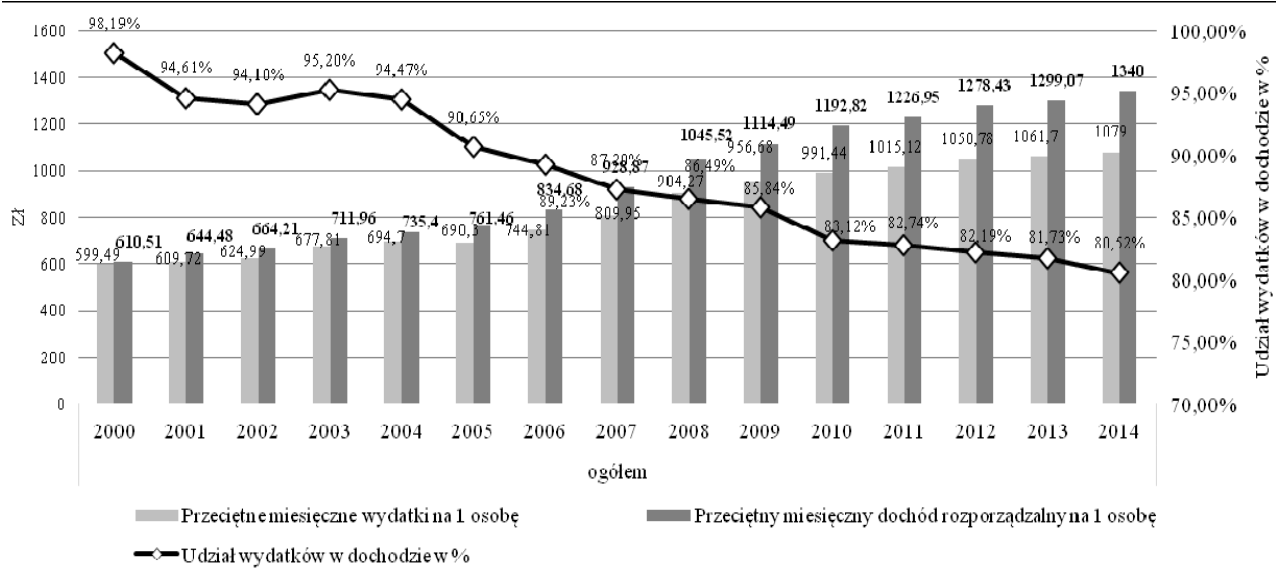

Rysunek 3

Poziom przeciętnych miesięcznych nominalnych dochodów i wydatków na osobę w gospodarstwie domowym oraz udział wydatków w dochodzie rozporządzalnym w latach 2000-2014 w Polsce

Źródło: Bank Danych Lokalnych, Warszawa 2015.

Według danych GUS przeciętne miesięczne nominalne wydatki w gospodarstwach domowych w 2014 roku były realnie wyższe o 1,63\% od wydatków z poprzedniego roku, a udział wydatków $\mathrm{w}$ dochodzie rozporządzalnym w 2014 r. wyniósł $80,52 \%$ i był niższy o 1,21 punktu procentowego niż w 2013 roku (rysunek 3). Warto zauważyć, że w latach 2000-2014, z wyłączeniem 2004 i 2005 roku, poziom przeciętnych miesięcznych nominalnych dochodów na osobę w gospodarstwie domowym systematycznie zwiększał się.

Jak wynika z danych zawartych na rysunku 4, mieszkańcy Polski największą część swoich przeciętnych wydatków przeznaczają na żywość i napoje bezalkoholowe $(24,4 \%)$. Na kolejnym miejscu znalazły się wydatki związane z użytko- 


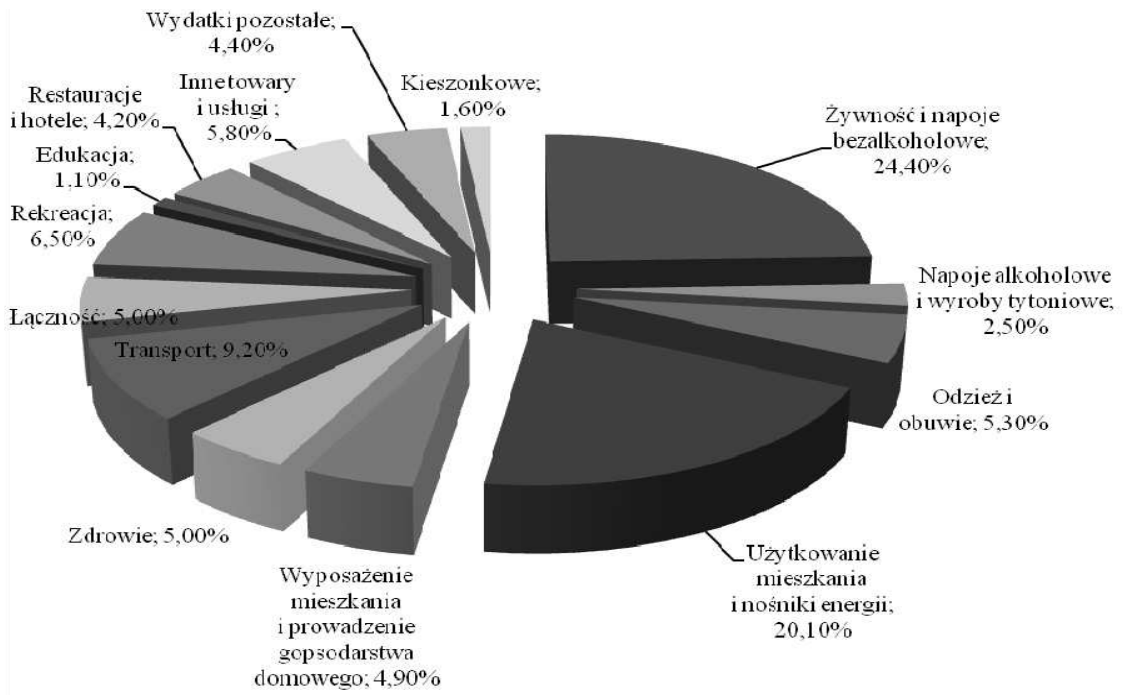

\section{Rysunek 4}

Przeciętne miesięczne wydatki na jedną osobę w gospodarstwach domowych w Polsce w 2014 roku

Źródło: Sytuacja gospodarstw domowych w świetle wyników badania budżetów gospodarstw domowych, GUS, Warszawa 2015, s. 5, www.stat.gov.pl [dostęp: 15.09.2015].

waniem mieszkań i nośnikami energii (20,1\%). Warto zauważyć, że dużą część z przeciętnych miesięcznych wydatków na jedną osobę w gospodarstwach domowych przeznacza się na transport $(9,2 \%)$. Najmniejszą zaś część swoich przeciętnych wydatków wydają mieszkańcy Polski na edukację (około 1,1\%).

Pojawia się zatem pytanie: ile środków pieniężnych przeznacza statystyczny polski konsument na żywność ekologiczną? Zgodnie z danymi Instytutu Badań na rzecz Rolnictwa Ekologicznego FIBL w 2013 roku statystyczny Polak wydał około 4 euro rocznie na żywność ekologiczną, dwa lata wcześniej zaś 3,1 euro [FiBL and IFOAM, The World of ...2014, s. 70]. Jest to bardzo niewielki procent wydatków na żywność ekologiczną. Nawet jeżeli uwzględnimy różnice dochodowe pomiędzy krajami, poziom ten jest znacznie niższy niż w większości państw o największych wydatkach na żywność ekologiczną (rysunek 5). Mieszkaniec Szwajcarii przeznaczył na ten cel 210 euro, Szwecji 163 euro, Luksemburga 157 euro, Niemiec zaś 93 euro. Niskiego poziomu wydatków na produkty ekologiczne w Polsce nie można zatem wiązać jedynie z niskim poziomem dochodów per capita, nawet jeżeli uwzględnimy efekt progu zakładający, iż powyżej określonego poziomu wzrost wydatków na produkty wyższego rzędu wykazuje szybszy wzrost wielkości zapotrzebowania. Należy to także łączyć ze świadomością konsumentów i ich preferencjami w tym także dostępnością ekologicznych produktów rolny. W tym kontekście można zauważyć, iż z jednej strony ponad 80\% 
krajowych produktów ekologicznych jest eksportowanych, a równocześnie na rynku rodzimym jest duży udział produktów pochodzących z importu (na ogół wysokoprzetworzonych) [Szanse i zagrożenia polskiego...2013, s. 5].

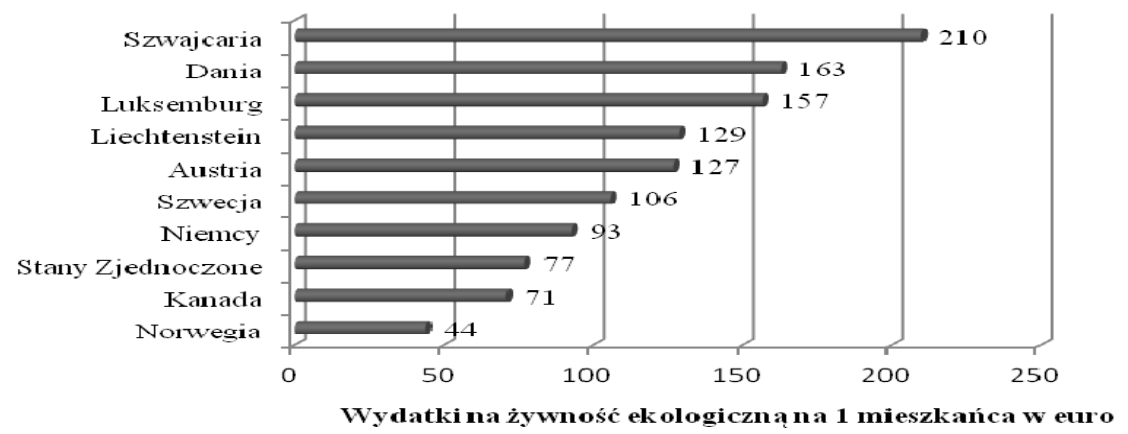

\section{Rysunek 5}

Kraje o największych wydatkach na żywności ekologicznej na jednego mieszkańca Źródło: FiBL and IFOAM, The World of Organic Agriculture. Statistic \& Emerging Trends 2015, s. 64, https://www.fibl.org/fileadmin/documents/shop/1663-organic-world-2015.pdf [dostęp: 15.09.2015].

Jak wynika z Raportu The World of Organic Agriculture. Statistic \& Emerging Trends 2015, wartość rocznych wydatków na żywność ekologiczną w przeliczeniu na 1 mieszkańca w Szwajcarii w 2013 roku była największa (rysunek 5). Na drugim miejscu znalazła się Dania, na kolejnych zaś mieszkańcy: Luksemburga, Liechtensteinu, Austrii, Szwecji, Niemiec, Stanów Zjednoczonych, Kanady i Norwegii. I w tym przypadku również można zauważyć, iż różnic w wielkości zakupów ekologicznych produktów rolnych nie można wiązać jedynie ani z poziomen dochodów per capita, ani też z wielkością krajowej produkcji rolnej.

\section{Żywność konwencjonalna a żywność ekologiczna}

Żywność ekologiczna to żywność wytwarzana bez użycia zarówno sztucznych nawozów, jak i pasz, zgodnie z prawami ekologii, a wszystko po to, aby chronić środowisko i dostarczać wysokiej jakości produkty rolne społeczeństwu. Ważne jest uświadomienie konsumentom różnic między rolnictwem konwencjonalnym a ekologicznym (tabela 3 ), a także tych wynikających ze znaczenia spożycia żywności opartej na różnych metodach wytwarzania dla zdrowia i samopoczucia człowieka. Niewątpliwie między żywnością, żywieniem a zdrowiem zachodzą ścisłe relacje, które ukazano na rysunku 6. Konsumentom warto przybliżać problematyką dotyczącą sposobów wytwarzania żywności. Rolnictwo 


\section{Tabela 3}

Rolnictwo konwencjonalne a rolnictwo ekologiczne

\begin{tabular}{|c|c|}
\hline Rolnictwo konwencjonalne & Rolnictwo ekologiczne \\
\hline $\begin{array}{l}\text { - } \text { - Sykorzystanie energii kopalin } \\
\text { - } \text { Intensywna eksploatacja zasobów aż do } \\
\text { ich degradacji } \\
\text { - } \text { Produkcja średniej jakości biologicznej } \\
\text { - Zła jakość przechowalnicza } \\
\text { - } \text { Maksymalizacja plonów } \\
\text { - Intensywność gospodarowania i obszar } \\
\text { nieskoordynowany z warunkami produkcji } \\
\text { i środowiska } \\
\text { - Zalecenia specjalizacji oparte głównie na } \\
\text { - } \text { kalkulacji ekonomicznej } \\
\text { biocydy, syntetyczne regulatory wzrostu } \\
\text { - Mechanizacja głównie w aspekcie uła- } \\
\text { twienia sobie pracy } \\
\text { - Skażenie środowiska }\end{array}$ & $\begin{array}{l}\text { - } \text { Gykorzystanie odnawialnych źródeł ener- } \\
\text { - Programowa ochrona krajobrazu } \\
\text { - Produkcja wysokiej jakości biologicznej } \\
\text { - Dobra jakość przechowalnicza } \\
\text { - Plon optymalny } \\
\text { - Obszar gospodarstwa i agrotechnika } \\
\text { - } \text { optymalna w stosunku do środowiska } \\
\text { zasady prawidłowego funkcjonowania } \\
\text { - gospodarstwa } \\
\text { - Ograniczenie lub zaniechanie chemizacji } \\
\text { - } \text { gechanizacja dostosowana do warunków } \\
\text { - Ochrona gleby i wody } \\
\text { - Produkty najwyższej jakości }\end{array}$ \\
\hline
\end{tabular}

Źródło: Rolnictwo konwencjonalne a rolnictwo ekologiczne, http://www.ppr.pl/artykul-roznice-miedzy-konwencjonalnym-a-ekologicznym-1778-dzial-11.php z 5.12.2001 [dostęp: 15.09.2015].

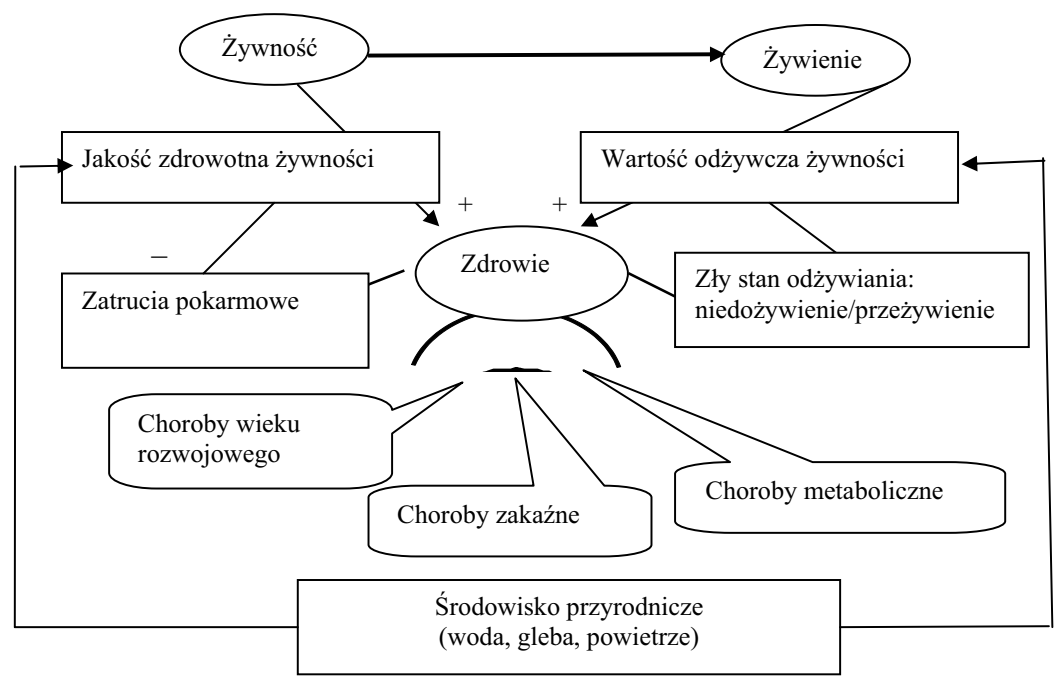

\section{Rysunek 6}

Związki między żywnością, żywieniem a zdrowiem

Źródło: T. Mossor-Pietraszewska, Relacje między żywnością, żywieniem a zdrowiem, [w:] J. Gawęcki i T. Mossor-Pietraszewska (red.), Kompendium wiedzy o żywności, żywieniu i zdrowiu, Wydawnictwo Naukowe PWN, Warszawa 2004, s. 6. 
ekologiczne rządzi się innymi regułami niż konwencjonalna produkcja rolna, ogranicza ujemny wpływ na środowisko. Wiąże się ono z podnoszeniem jakości produktów rolnych, wykorzystaniem osiągnięć nauk biologicznych, a przede wszystkim ochroną gleby, wody i powietrza. Warto zaważyć, że barierą popytu na produkty ekologiczne jest dla wielu konsumentów cena tych produktów. Jednakże konsumenci przy dokonywaniu zakupów kierują się różnymi czynnikami, wśród których można wyróżnić nie tylko czynniki ekonomiczne, ale także psychologiczne czy społeczno-kulturowe. Nie ulega wątpliwości, że poznanie konsumentów i kryteriów, którymi kierują się w procesie podejmowania decyzji, pozwala lepiej dostosować ofertę handlową do ich preferencji i oczekiwań [Urban i Michałowska 2013, s. 108].

Do głównych czynników determinujących cenę produktów przyjaznych dla środowiska zalicza się m.in.: koszty produkcji i programów badawczo-rozwojowych ukierunkowanych prośrodowiskowo, koszty dystrybucji, redystrybucji i promocji, poziom świadomości ekologicznej konsumentów, elastyczność cenową popytu na dany produkt ekologiczny, relacje między wielkością podaży i popytu na te produkty [Jedlińska i Zaremba-Warnke 2009, s. 141-142]. Rozwój ekologicznych gospodarstw rolnych i w konsekwencji produktów ekologicznych wymaga ukształtowania systemu instytucjonalnego pozwalającego wyodrębnić w sposób transparentny i wiarygodny dla konsumenta produkty ekologiczne. Służy temu wprowadzone w krajach UE systemy certyfikacji, których rola rośnie także w ujęciu wymiany międzynarodowej [Harms i Linton, s. 9].

Jak już wcześniej wspomniano, żywność, żywienie i zdrowie to obszary ściśle ze sobą powiązane, w których jakość zdrowotna i wartość odżywcza zajmują centralne miejsce. T. Mossor-Pietraszewska definiuje jakość zdrowotną żywności jako szeroko rozumianą nieszkodliwość, na którą głównie mają wpływ sanitarno-higieniczne warunki produkcji, przetwórstwa i obrotu handlowego, wartość odżywcza informuje zaś o zawartości niezbędnych dla prawidłowego funkcjonowania organizmu ludzkiego składników, ich wzajemnych proporcji i biodostępności [Mossor-Pietraszewska 2004, s. 6]. Środowisko przyrodnicze decyduje zarówno o jakości zdrowotnej, jak i wartości odżywczej żywności.

Na uwagę zasługuje również fakt, że zarówno w zakresie jakości, jak i wartości odżywczej żywności prowadzi się wiele badań w celu dokonania oceny żywności pochodzącej z upraw konwencjonalnych, jak i gospodarstw ekologicznych. Jak wynika z badań w większości przypadkach, zarówno jakość, jak i wartość odżywcza żywności pochodzącej z upraw ekologicznych jest większa, jednakże zdarzają się wyniki stwierdzające brak różnic w ocenie żywności ekologicznej i konwencjonalnej [Szołtysek 2004, s. 23-26]. Resumując uzyskane wyniki badań przez różnych ich autorów, należy jednak stwierdzić, że „można i należy 
oczekiwać lepszej jakości zdrowotnej (...), a co więcej, jak potwierdzają wyniki badań - to właśnie metody ekologiczne pozwalają zmniejszyć dostarczanie azotanów i azotynów do organizmu człowieka o 50\% [Szołtysek 2004, s. 29]".

\section{Podsumowanie}

W latach 2004-2014 wzrosła w Polsce zarówno liczba ekologicznych producentów rolnych, jak i liczba przetwórni ekologicznych. Analiza struktury ekologicznych upraw rolnych w 2014 roku wykazała, że największy udział w powierzchni upraw rolnych miały rośliny na paszę oraz łąki i pastwiska, czyli obszary pośrednio związane z produkcją ekologiczną. Warto również zauważyć, że w Polsce popyt na żywność ekologiczną jest wciąż niewielki na tle krajów o największej jej konsumpcji na jednego mieszkańca. Pomimo obserwowanych przemian w spożyciu żywności zmiany w Polsce pod tym względem przebiegają znacznie wolniej w porównaniu do krajów o najwyższych wydatkach na żywność ekologiczną na jednego mieszkańca. Poziom i struktura konsumpcji są niewatpliwie determinowane przez dochody konsumentów, nie można jednak przyjąć, iż dochód jest jedynym wyznacznikiem różnicującym zachowania konsumentów na rynku żywności ekologicznej. Rozwojowi rynku żywności sprzyja nie tylko rosnąca zamożność społeczeństwa, ale także coraz większa świadomość ekologiczna. Dostrzeżenie zależności między żywnością, którą codziennie spożywamy, a poziomem samopoczucia i stanem zdrowia staje się kluczowe w rosnącym popycie na te produkty. Wydaje się jednak, że w przyszłości coraz większego znaczenia nabierać będzie troska o zdrowie, dobre samopoczucie, dbałość o środowisko, co niewątpliwie znajdzie odzwierciedlenie w decyzjach zakupowych konsumentów. Przewiduje się, że zasięg i udział w rynku żywności ekologicznej będzie się zwiększał, jednakże dominujący udział będą miały wciąż produkty wytwarzane metodami konwencjonalnymi ze względu m.in. na dużą efektywność ekonomiczna. Czynnikiem zwiększającym znaczenie rolnictwa ekologicznego, obok już wspomnianych, stały się także zmiany w strukturze finansowego wsparcia rolnictwa, w coraz większym stopniu uwzględniające aspekty środowiskowe i społeczne.

\section{Literatura}

Bank Danych Lokalnych, Warszawa 2015.

Dane GUS, Rolnictwo w 2014, [za:] Raport o stanie rolnictwa ekologicznego w Polsce w latach 2013-2014, Inspekcja Jakości Handlowej Artykułów Rolno-Spożywczych, Warszawa 2015, http://www.ijhar-s.gov.pl/pliki/A-pliki-z-glownego-katalogu/ether- 
net/2015/wrzesien/Raport\%20o\%20stanie\%20rolnictwa\%20ekologicznego\%20w\%20 Polsce\%20w\%20latach\%202013-2014.pdf, [dostęp: 15.09.2015].

BATURO W. i in. (red.), 2004: Nowa encyklopedia powszechna PWN, Wydawnictwo Naukowe PWN, Warszawa.

CLAY J., 2013: World Agriculture and Environment, World Wildlife Fund, Washington.

DĄBROWSKA A., BYLOK F., JANOŚ-KRESŁO M., KIEŁCZEWSKI D., OZIMEK I., 2015: Kompetencje konsumentów, PWE, Warszawa.

Eursostat, http://appsso.eurostat.ec.europa.eu/nui/submitViewTableAction.do, [dostęp: 15.09.2015].

FiBL and IFOAM, The World of Organic Agriculture. Statistic \& Emerging Trends 2014, https://www.fibl.org/fileadmin/documents/shop/1636-organic-world-2014.pdf, [dostęp: 15.09.2015].

FiBL and IFOAM, The World of Organic Agriculture. Statistic \& Emerging Trends 2015, https://www.fibl.org/fileadmin/documents/shop/1663-organic-world-2015.pdf, [dostęp: 15.09.2015].

HARMS R., LINTON J.D., 2015: Willingness to Pay for Eco-Certified Refurbished Products: The Effects of Environmental Attitudes and Knowledge, Journal of Industrial Ecology, no. 1 .

Rolnictwo konwencjonalne a rolnictwo ekologiczne, http://www.ppr.pl/artykul-roznicemiedzy-konwencjonalnym-a-ekologicznym-1778-dzial-11.php z 5.12.2001, [dostęp: 15.09.2015].

JEDLIŃSKA M., ZAREMBA-WARNKE S., 2009: Ksztaltowanie cen produktów, [w:] S. Zaremba-Warnke (red.), Marketing ekologiczny, Wydawnictwo Uniwersytetu Ekonomicznego we Wrocławiu, Wrocław.

KUŁYK P., 2013: Finansowe wsparcie rolnictwa w krajach o różnym poziomie rozwoju gospodarczego, Wydawnictwo UE w Poznaniu, Poznań.

ŁUCZKA-BAKUŁA W., 2007: Rynek żywności ekologicznej, PWE, Warszawa.

MOSSOR-PIETRASZEWSKA T., Relacje między żywnościa, żywieniem a zdrowiem, [w:] J. Gawęcki i T. Mossor-Pietraszewska (red.), Kompendium wiedzy o żywności, żywieniu i zdrowiu, Wydawnictwo Naukowe PWN, Warszawa 2004.

Raport o stanie rolnictwa ekologicznego w Polsce w latach 2013-2014, Inspekcja Jakości Handlowej Artykułów Rolno-Spożywczych, Warszawa 2015, http://www.ijhar-s.gov. pl/pliki/A-pliki-z-glownego-katalogu/ethernet/2015/wrzesien/Raport\%20o\%20stanie $\%$ 20rolnictwa\%20ekologicznego\%20w\%20Polsce\%20w\%20latach\%202013-2014.pdf, [dostęp: 15.09.2015].

Rozporządzenie Rady (WE) nr 834/2007 z dnia 28 czerwca 2007 r. w sprawie produkcji ekologicznej i znakowania produktów ekologicznych, Dz.Urz. L 189/1 z 20.07.2007 r.

RUNOWSKI H., 2009: Rolnictwo ekologiczne - rozwój czy regres, Roczniki Nauk Rolniczych, Seria G, T. 96, z. 4.

Sytuacja gospodarstw domowych w świetle wyników badania budżetów gospodarstw domowych, GUS, Warszawa 2015, www.stat.gov.pl, [dostęp: 15.09.2015]. 
Szanse i zagrożenia polskiego rolnictwa ekologicznego w perspektywie lat 2014-2020, 2013: Biuro Analiz i Dokumentacji, Kancelaria Senatu, Warszawa.

SZOŁTYSEK K., 2004: Zarys problematyki żywności ekologicznej, Wydawnictwo Akademii Ekonomicznej im. Oskara Langego we Wrocławiu, Wrocław.

URBAN S., MICHAŁOWSKA M., 2013: Czynniki wptywajace na zachowania konsumentów w zakresie wyboru targowisk jako miejsca zakupu produktów konsumpcyjnych na przykładzie województwa lubuskiego, Roczniki Ekonomii Rolnictwa i Rozwoju Obszarów Wiejskich, t. 100, z. 2.

Ustawa z dnia 25 czerwca 2009 roku o rolnictwie ekologicznym, Dz.U. nr 116, poz. 975, z późn. zm.

ZEGAR J.S., 2012: Wspótczesne wyzwania rolnictwa. Paradygmaty-Globalizacja-Polityka, Wydawnictwo Naukowe PWN, Warszawa.

ŻELEZIK M., 2009: Dlaczego rolnictwo ekologiczne? Rocznik Świętokrzyski Seria B - Nauki Przyrodnicze 30.

\section{Abstrakt}

Procesy zachodzące w środowisku przyrodniczym pod wpływem realizacji industrialnych koncepcji rozwoju rolnictwa wywołały istotną zmianę modelu produkcji i konsumpcji i zwrócenie się w większym stopniu w stronę rolnictwa zrównoważonego, opartego na zgodnym połączeniu celów społecznych, środowiskowych i ekonomicznych. Zachowując właściwe proporcje między tymi podsystemami, dąży się do zapewniania równowagi międzypokoleniowej i wewnątrzpokoleniowej. Realizacji tych zasad służy m.in. rozwój rolnictwa ekologicznego. Skoncentrowanie się na żywności ekologicznej wydaje się szczególnie istotne wobec rosnącej świadomości konsumentów, dążeniu ich do jak najlepszego zaspokojenia swoich potrzeb poprzez dobór produktów o odpowiednich parametrach odżywczych i zdrowotnych. Produkt ekologiczny stanowi szansę na poprawę konkurencyjności w rolnictwie, zwłaszcza europejskim, umożliwiając racjonalne gospodarowanie zasobami poprzez wdrażanie założeń ekonomii zrównoważonego rozwoju. W artykule przedstawiono stan i tendencje rozwoju rolnictwa ekologicznego w Polsce w latach 2004-2014 na tle przemian zachodzących w krajach UE. Ponadto ukazano strukturę wydatków w polskich gospodarstwach domowych, w tym poziom wydatków przeznaczonych na żywność ekologiczną, na tle krajów o największej konsumpcji na jednego mieszkańca.

Słowa kluczowe: zrównoważony rozwój, rolnictwo ekologiczne, konsumpcja zrównoważona, żywność pochodząca z upraw ekologicznych, żywność konwencjonalna, dochody i wydatki gospodarstw domowych 


\title{
The status of development of organic farming in Poland in the years 2004-2014
}

\begin{abstract}
Processes occurring in the natural environment due to the implementation of industrial concepts of agricultural development led to a significant change of the production and consumption models. The approach shifted to a more balanced one, leading to the sustainable development of agriculture and rural areas based on the combination of social, environmental and economic goals. Whilst ensuring an appropriate balance between these systems, there is an attempt to achieve balance within and between generations. The focus on organic food matches well with these trends and seems particularly important, given growing awareness of consumers and their willingness to best meet their needs through the selection of products with the appropriate nutritional and health parameters. Ecological product provides an opportunity to improve the competitiveness of agriculture, especially in Europe, enabling rational management of resources by implementing the economics of sustainable development. The article presents the status and trends of development of organic farming in Poland in the years 2004-2014. In addition, the structure of expenditure in Polish households is shown, including the level of spending on organic food against the background of the countries with the highest per capita consumption.
\end{abstract}

Key words: sustainable development, organic farming, sustainable consumption, foods derived from organic farming, conventional foods, household income and expenditure of households 